\title{
Editorial: Geotourism and Geoconservation
}

\author{
Thomas Alfred Hose
}

Received: 4 February 2012 /Accepted: 15 February 2012 /Published online: 6 March 2012

(C) Springer-Verlag 2012

Welcome to this special issue of Geoheritage with its set of themed papers on 'geotourism and geoconservation'. The authors of every paper have a combined practitioner and academic interest in understanding and promoting this important interrelationship, the pursuit of which avoids the ills of geoexploitation (Hose 2007). There can be no doubt, as a pioneer in European geoconservation and geological outreach noted, that "Raising public awareness is the key to sustainable geoconservation success." (Gonggrijp 2000, p. 44). Geotourism has had a key role over the last decade or so in such promotional work and has undoubtedly made a major contribution to bringing geology to the attention of a greater number of the populace than was thitherto achieved. Geotourism is a relatively newly recognised but rapidly developing form of geology-based tourism. It was initially recognised and defined in the United Kingdom (UK) where it was also the first focus of dedicated university research (Hose 2003). Its first widely published definitions (Hose 1995, 1997, 2000) were specifically related to on-site interpretative provision for the purpose of geoconservation. These early definitions and the discussions around them also recognised the significant underpinnings provided to geotourism by social history and industrial archaeology, elements later included in most geopark developments. A new definition of geotourism, and the background behind its necessary development, is given in two of the papers (Hose, this volume; Hose and Vasiljević, this volume) herein presented.

As variously redefined and discussed in Europe and elsewhere over the past 15 years, geotourism has invariably had a geological basis and encompassed an examination of the physical basis, interpretation and promotion of geosites and

T. A. Hose $(\bowtie)$

School of Earth Sciences, University of Bristol,

Wills Memorial Building, Queens Road,

Clifton, Bristol BS8 1RJ, UK

e-mail: gltah@bristol.ac.uk geomorphosites. Two already published Australasian-based dedicated geotourism books (Dowling and Newsome 2006; Newsome and Dowling 2010) both adopted the geological basis of geotourism and supported the original approach adopted by Hose $(1995,2000)$. Likewise, a recent major national inventory of geotourism resources for Iran (Amrikazemi 2010) has adopted and promoted the geological basis of geotourism; the Iran volume is also a fine example of how to present a country's geoheritage as both an asset and something worthy of appreciation at a variety of scales in a readily understood local format. It also highlights, as do the two Australasian-based books, that modern geotourism and the discussion around it has spread far from its UK origins and been globally embraced.

Geotourism, as originally promoted, also encompasses geoscientists' lives, work, collections, publications, artworks, field notes, personal papers, workplaces, residences and even their final resting places and monuments (Hose 1996). The linked geotourism themes of geoconservation, geohistory and geo-interpretation are updated (Hose, this volume) and the latter theme explored (Burek, this volume; Wrede and Muegge-Bartolovic, this volume) and especially evaluated (Crawford and Black, this volume; Moreira, this volume), in several of this issue's papers. Geohistory is particularly examined in two papers (Gordon, this volume; Hose, this volume). At the outset of its inception, it was envisaged that geotourism would both constituency build and provide some funding for geoconservation when governments were unwilling (and now in these austere times conveniently suggesting themselves unable) to provide such financial support.

Geotourism was developed in the UK as consequence of the late 1980s recognition by school, university and museum geologists of the increasing losses of mines and quarries to unsympathetic after-uses and reclamation programmes. Natural geological exposures were also increasingly being lost due to unsympathetic civil engineering projects for major buildings, 
transport and coastal defence. Even long classic geology teaching sites were affected, and this was brought to this Guest Editor's attention, stimulating the geotourism work, in an area he had partly field-mapped as an undergraduate and to which he later took geology student field parties. Over some 20 years, he witnessed in that area, the Crich inlier (Fig. 1) and the environs of the town of Matlock in the Peak District in England, the loss of major quarry sites to landfill (Figs. 2 and 3) and access restrictions into others on the grounds of health and safety; privacy concerns for new buildings with their private grounds in and around old quarries also reduced access. Consequently, many specific rock sequences and beds are now no longer exposed either in the district or anywhere else. It was perhaps only natural that the first published geotourism study (Hose 1994) was an assessment of the visitors to the National Stone Centre situated within $10 \mathrm{~km}$ of Crich and Matlock. Places such as the National Stone Centre, which is situated within a redundant limestone quarry, can stimulate an early and potentially lifelong interest in geology. Both extractive industry and natural exposure sites are the literal training grounds for student geologists, some of whom will go on in the future to recognise and provide the raw geological materials that sustain modern economies.

Within Europe, similar concerns to those in the UK over the loss of geosites and geomorphosites led to the establishment in 1993 of The European Association for the Conservation of the Geological Heritage (ProGEO). Working

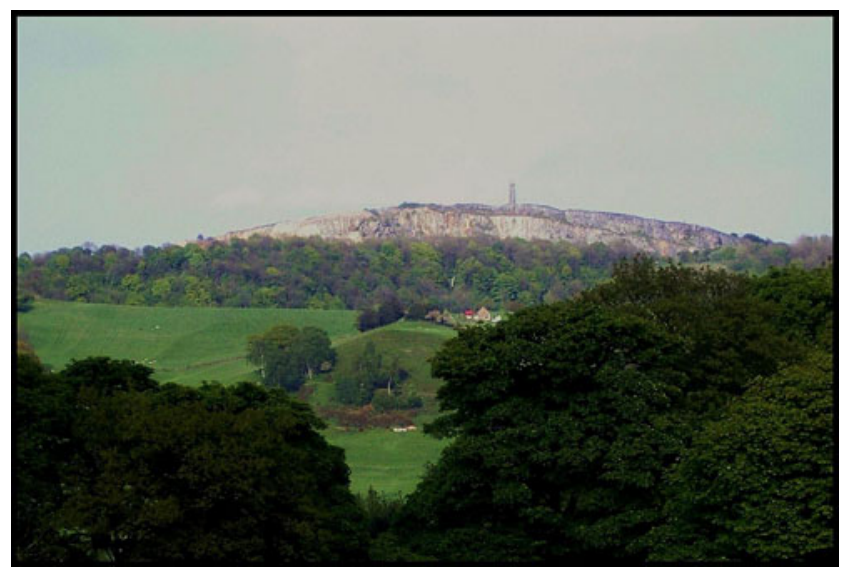

Fig. 1 The Crich inlier in the Peak District of England: In this view, looking north-east from near Whatstandwell, the hill in the distance is the folded core of an inlier of Lower Carboniferous limestone of Visean series age. It is cut by a large working quarry and several redundant quarries; the floor of one redundant quarry houses The National Tramway Museum, established in 1959. The hill has been mined, probably since Roman times, for lead ore and its slopes are littered with numerous capped and uncapped mine shafts. The rocks surrounding the hill are Upper Carboniferous coarse-grained sandstones, mudstones and shales of the Millstone Grit Group of Namurian series age. Despite the extensive mining and quarrying of the area, its landscape still has considerable aesthetic appeal and attracts day visitors and tourists from the major towns, such as Derby and Nottingham, to the south of the Peak District (Copyright T.A. Hose)

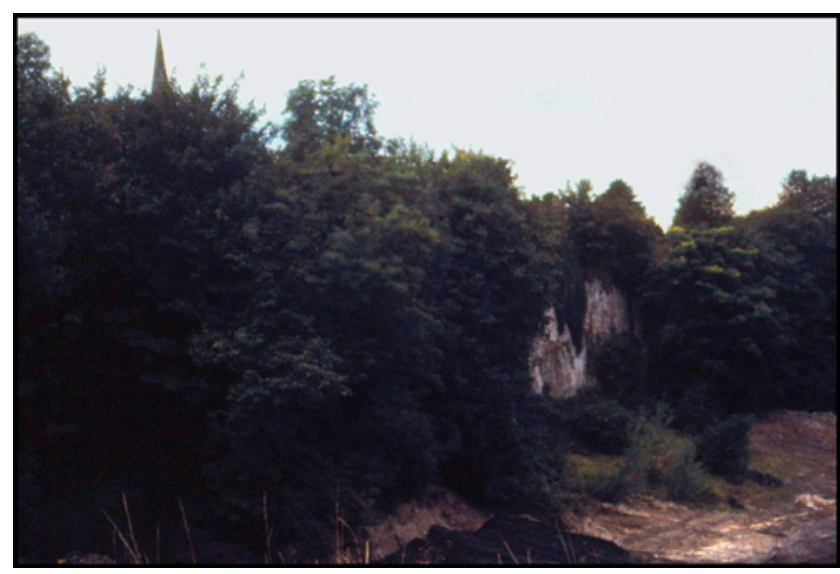

Fig. 2 St. Michael's Quarry, Crich (in September 1986) during the first phase of landfill operations: Note the spire (top left) of the church which gave its name to this limestone quarry can be seen above the trees that hide the road running along the edge of the quarry. Before the landfill operation started, there was exposed at the foot of the large quarry face, in the Lower Carboniferous limestone of the Monsal Dale Limestone Formation (Visean series age), a fossil-rich coral bed now no longer seen anywhere in the district. The quarry was fairly accessible to geologists for many years via a steep path to the right in this view. During the landfill operations, geologists were denied access, and no 'rescue', in situ recording and collecting from strata now no longer easily accessible in the district was possible; a 'window' looking into deep time has been securely closed (Copyright T.A. Hose)

through its member country and regional working groups, ProGEO has successfully developed and promoted geoconservation across Europe, especially through the GEOSITES project established in 1996. Its third international symposium, held in Madrid in 1999, led to the publication of a much cited and influential volume (Barretino et al. 2000)

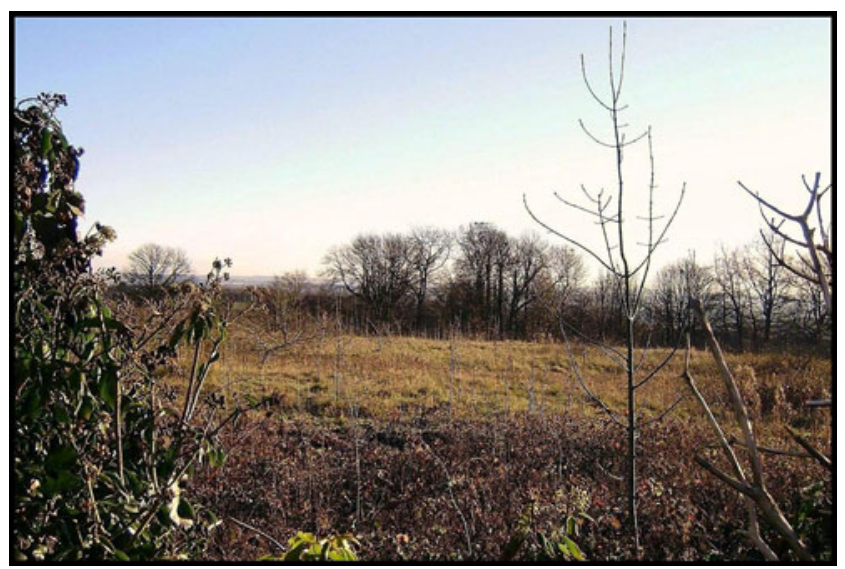

Fig. 3 St. Michael's Quarry, Crich (in November 2010) after its complete infilling: This view is from the road that runs alongside the church above the now completely buried cliff (seen in Fig. 2) of the former quarry. The quarry has been completely filled in, and the former slope of the hillside has been more or less restored to its original profile. Trees and shrubs have been planted to cover the landfill area. The only obvious remaining evidence left of the old quarry is the decaying fence and warning notice some $50 \mathrm{~m}$ away from the vantage point from which this photograph was taken (Copyright T.A. Hose) 
with contributions from acknowledged international authorities on geoconservation and geotourism. The emergence of the journal Geoheritage seems a natural but long overdue development from that and similar ProGEO publications. The world's first dedicated geotourism conference, with international attendees and contributors, was held in the UK in Belfast in 1998 (Robinson 1998), but it did not publish any proceedings.

There were several geotourism conferences in Europe in the opening decade of this century, the last of which was Geotrends'10 held in Novi Sad, Serbia (Hose et al. 2011), and most of these published at least an abstracts volume. There have also been three so-called global geotourism conferences (in 2007, 2009 and 2011), but these have been mainly southern hemisphere events with limited contributions and influence from the key European geotourism academics. The present decade has witnessed a number of geotourism conferences, and 2012 alone already has in the calendar for May the ' 1 st International Congress on Management and Awareness in Protected Volcanic Landscapes' hosted within Spain's La Garrotxa Volcanic Zone Natural Park, and for October the 'Appreciating Physical Landscapes: Geotourism 1670-1970' geohistory conference hosted by the Geological Society of London in its Burlington House apartments that incidentally house one of the world's finest geology libraries. It is to be hoped that both European conferences will publish a set of proceedings that will strengthen our knowledge and understanding of geotourism. Europe is also where the first journal dedicated to geotourism, Geoturystyka, was founded in Poland in 2004. The International Association for Geotourism, or IAGt, was also concomitantly founded in Poland, and there are also decidedly national geotourism organisations such as that established in Italy.

The main reason for the original UK development of geotourism was to promote and provide some funding for geoconservation (Hose 1995, 2011). The development and management of such geoconservation strategies at a regional and national scale, that also support geotourism, have been pioneered in the UK and are described in the paper on Wales (Burek, this volume). The development of analytical empirical tools, at the scale of both individual sites and regional landscapes, for which the ability to collect, analyse and present complex data is becoming a necessary pre-requisite for good geoconservation management and geotourism site and area selection; an excellent example of some innovative work in this field is provided herein from Spain (MartínDuque, García and Urquí, this volume). A geoconservation focus gives geotourism some overlap with other forms of natural heritage tourism such as 'environmental', 'naturebased' and 'eco-tourism'. Possibly the major natural global geotourism interest is in cave tourism, although this can also be expanded to old mines and waterfalls. In this set of papers, the former are considered at the national scale for
Italy (Garofano and Govoni, this volume) and the latter as case studies from Brazil (Moreira, this volume) and Scotland (Gordon, this volume), although the waterfalls considered lie at each end of the size spectrum. Both cave (and for that matter, mine) and waterfall tourism can be traced back to at least the seventeenth century in Europe (Hose 2008). However, volcanic geotourism has a history from at least the eighteenth century (Hose 2010), and the interpretation and presentation of two of its major historic UK sites, The Giant's Causeway and the Isle of Staffa, are considered in two papers (respectively, Crawford and Black, this volume; and Gordon, this volume).

Sometimes portrayed as a minor aspect of tourism provision, geotourism is at the casual level one of the most widely practiced forms of natural souvenir collecting; most tourists have at some time collected a pebble or two, even if only when a child at the beach. It is perhaps no surprise then that Gideon Mantell, one of the pre-eminent popularisers of geology in the nineteenth century, drew attention to a refined version of this activity for adults; in his first truly pocketable geology guide to southern England, he wrote that at Rottingdean near Brighton such beach pebbles were "...collected by visitors and when cut and polished are used for bracelets and other ornamental purposes ..." (Mantell 1833, p. 41). He later went on to publish the genesis of the modern illustrated geology field guide (Mantell 1847) that was so popular it ran to three editions. It can still be read with profit today and is much sought after. This is a vindication of Mantell's understanding of what was needed to introduce excursionists, the forerunners of modern geotourists, to geology and how to then fully engage the attention of the reader of a guide book; many modern authors would do well to either learn from or even duplicate his approach! Whilst geotourism has been described as a form of 'niche' (Hose 2005) or 'special interest' tourism' (Jenkins 1992), these approaches do not necessarily imply it is restricted to a minority of tourists because they are both actively growing tourism market segments. An early Australian study (Jenkins 1992), although employing the term 'fossicking', noted that what is now termed geotourism was then a popular activity in Australasia and North America and comprised one of the world's largest single hobby groups. Tourists in the United States of America (USA) have had a long association with geotourism in the form or 'rock hounding' and dinosaur hunting where a mid-1990s study recognised that "Protecting and conserving resources that provide tourism or recreational experiences creates challenges for the development and management of natural heritage areas" (O'Halloran 1996, p. 495).

Given that study and similar early ones from the USA and Canada, it is then rather odd that National Geographic ignored such domestic, let alone European studies on, geologyfocussed geotourism in promoting a more generalist geographical approach. That approach with its emphasis on the natural and human attributes that make a place worth visiting (Tourtellot 2006) is just a rebranding of long-standing types of 
already recognised tourism provision. Its adoption, especially in geoparks and protected landscapes, could actually compromise geoconservation. Geoparks had in much of their geotourist provision already recognised that geology and its associated landscape have a major effect on the economic, social and cultural history of an area. Whilst the majority of geoparks have long embraced the geological approach to geotourism, there has been the recent exception of the organising committee of a geoparks conference, held within a Portuguese geopark noteworthy for the excellence of its geological interpretative provision and geoconservation work, remarkably opting in late 2011 to promote the National Geographic approach. This adoption is despite the acceptance and promotion of the original geology-focussed approach and definition (Hose 1995) by UNESCO in its initial geopark documentation (Patzak and Eder 1998; UNESCO 2000) as a fundamental rationale and underpinning for geoparks worldwide. Geotourism with a particular emphasis on rural localities and geoparks has burgeoned from the opening of the present century. It is perhaps surprising for anyone unfamiliar with geohistory that many of today's supposed rural areas, such as the Lake District National Park and the Peak District National Park in the UK, have a long mining and quarrying heritage. The previous emphasis particularly in the UK on geotourism associated with such mining and quarrying heritage continues to be a major strand in geotourism; with the often associated retention of industrial buildings and historic transport infrastructure geotourism can be considered a form of 'heritage tourism'. This emphasis in Europe is reflected in the case study of the Ruhr Geotrail (Wrede and Muegge-Bartolovic, this volume) and various examples from southern Europe (Hose and Vasiljević, this volume).

Geotourism is a developing field of international academic study. The papers in this special issue of Geoheritage are as geographically and topically comprehensive a set, despite those individuals approached because of the quality of their work who were either unable to prepare or eventually submit a finished paper, as it was possible to commission from academic practitioners with an interest in generating a sound theoretical and analytical underpinning. Its papers cover a range of interests from pure definitions of geotourism to a variety of studies related to specific geotourism topics and destinations. Perhaps the two major geographical omissions are papers from the USA and China. In the former, the foundations of the conservation of whole landscapes with spectacular geology were established in the nineteenth century and of environmental and landscape interpretation in the early to mid-twentieth century. In the latter, geoparks have been enthusiastically embraced and significant investment made in their development. However, in the USA, this early emphasis on geology has been lamentably compromised by National Geographic's approach to geotourism. That some in the
European geoparks movement have recently seemingly embraced this diminution of geology in geotourism, without any seeming pan-European geoparks' or geoconservation bodies' agreement on the matter, is to be lamented and rectified; this set of papers should help promote that outcome.

No one volume, whether a set of journal papers or a book, could honestly claim to adequately cover the current breadth of modern geotourism in terms of the nature of provision and geographical coverage, together with its theoretical underpinnings. The papers in this special issue can however justifiably claim to represent much of that breadth through the inclusion of specific case studies and significant overview material. I commend this special issue to you in the hope that it will stimulate further examination, analysis and discussion of geotourism and lead to new researchers becoming engaged in its study and subsequently publishing their work in Geoheritage. The individual authors are to be wholeheartedly thanked for agreeing to prepare their papers and for accepting the rigours of the necessarily lengthy review and revision process that at times must have seemed pedantic. It is hoped they will consider their labours justified and the end result a worthwhile contribution to a better appreciation of geotourism. Putting together this set of papers, at the original invitation of Bill Wimbledon, would not have been possible without the strong editorial support of José Brilha and the attention to detail of the Springer editorial team, but it is to José, for keeping track of the various papers through the lengthy review and revision process, that especial thanks are gladly extended. It is hoped that the geoconservation aspect of this set of geotourism papers is a fitting dedication to the work of the late Gerard Gonggrijp.

Tom Hose (Guest Editor)

Chalton, Bedfordshire, England

\section{References}

Amrikazemi A (2010) Atlas of geopark and geotourism resources of Iran: geoheritage of Iran. Geological Survey of Iran, Tehran

Barretino D, Wimbledon WP, Gallego E (eds) (2000) Geological heritage: its conservation and management. Instituto Tecnologico Geominero de Espana, Madrid

Dowling RK, Newsome D (eds) (2006) Geotourism. Elsevier, London

Gonggrijp GP, Gonggrijp GP (2000) Planning and management for geoconservation. In: Barretino D, Wimbledon WP, Gallego E, Barretino D, Wimbledon WP, Gallego E (eds) Geological heritage: its conservation and management. Instituto Tecnologico Geominero de Espana, Madrid, pp 29-45

Hose TA (1994) Telling the story of stone - assessing the client base. In: O'Halloran D, Green C, Harley M, Stanley M, Knill J (eds) Geological and landscape conservation. Geological Society, London, pp 451-457

Hose TA (1995) Selling the story of Britain's stone. Environ Interpretation 10(2):16-17 
Hose TA (1996) Geotourism, or can tourists become casual rock hounds? In: Bennett MR (ed) Geology on your doorstep. The Geological Society, London, pp 207-228

Hose TA (1997) Geotourism - selling the Earth to Europe. In: Marinos PG, Koukis GC, Tsiambaos GC, Stournaras GC (eds) Engineering geology and the environment. AA Balkema, Rotterdam, pp 2955-2960

Hose TA (2000) European geotourism - geological interpretation and geoconservation promotion for tourists. In: Barretino D, Wimbledon WP, Gallego E (eds) Geological heritage: its conservation and management. Instituto Tecnologico Geominero de Espana, Madrid, pp 127-146

Hose TA (2003) Geotourism in England: A two-region case study analysis. Birmingham, unpublished $\mathrm{PhD}$ thesis, University of Birmingham, Birmingham

Hose TA (2005) Geo-tourism - appreciating the deep time of landscapes. In: Novelli M (ed) Niche tourism: contemporary issues, trends and cases. Elsevier, London, pp 27-37

Hose TA (2007) Geoconservation versus geo-exploitation and the emergence of modern geotourism. In: Röhling HG, Breitkreuz ChTh, Duda Th, Stackebrandt W, Witkowski A, Uhlmann O (eds) Abstracts volume, Geo-Pomerania Szczecin 2007 Joint Meeting PTG-DGG: geology cross-bordering the Western and Eastern European platform, 24-26 September 2007. University of Szczecin, Szczecin, p 122

Hose TA (2008) Towards a history of geotourism: definitions, antecedents and the future In: Burek CV and Prosser CD (eds) The History of Geoconservation: Geological Society Special Publication No. 300, Geological Society, London, pp 37-60

Hose TA (2010) Volcanic geotourism in West Coast Scotland. In: Erfurt-Cooper P, Cooper M (eds) Volcano and geothermal tourism: sustainable geo-resources for leisure and recreation. Earthscan, London, pp 259-271

Hose TA (2011) The English origins of geotourism (as a vehicle for geoconservation) and their relevance to current studies. Acta Geographica Slovenica 51-2(2011):343-360

Hose TA, Markovic SB, Komac B, Zorn M (2011) Geotourism-a short introduction. Acta Geographica Slovenica 51-2(2011):339 342

Jenkins JM (1992) Fossickers and rockhounds in Northern New South Wales. In: Weiler B, Hall CM (eds) Special interest tourism. Belhaven Press, London, pp 129-140

Mantell GA (1833) The geology of the south-east of England. Longman, London

Mantell GA (1847) Geological excursion round the Isle of Wight and along the adjacent Coast of Dorsetshire. HG Bohn, London

Newsome D, Dowling RK (eds) (2010) Geotourism: The Tourism of Geology and Landscape. Goodfellow, Oxford

O'Halloran RM (1996) Dinosaurs for tourism: Picket Wire Canyon and the Rocky Mountain palaeontological tourism initiative, Colorado, USA. In: Harrison LC, Husbands W (eds) Practicing responsible tourism: international case studies in tourism planning, policy and development. Wiley, New York, pp 495-508

Patzak M, Eder W (1998) UNESCO Geopark, a new programme-a new UNESCO label. Geologica Balcania 28(3-4):33-35

Robinson E (1998) Tourism in geological landscapes. Geology Today 14(4):151-153

Tourtellot JB (2006) Geotourism for your community: a guide for a geotourism strategy. National Geographic, Washington

UNESCO (2000) UNESCO Geoparks Programme Feasibility Study, August 2000. UNESCO, Paris 